\title{
Comparison of RT-qPCR and RT-Digital PCR for Detection and Quantification of BCR-ABL1 Transcripts in Chronic Myeloid Leukemia
}

\author{
RT-qPCR ve RT-Dijital PCR Yöntemlerinin Kronik Myeloid Lösemi'de BCR-ABL1 Transkriptlerini Tespit Etme ve \\ Ölçümleme Başarılarının Karşılaştırılması
}

Taha Bahsi, Haktan Bağış Erdem

University of Health Sciences, Dr. Abdurrahman Yurtaslan Ankara Oncology Training and Research Hospital, Department of Medical Genetics, Ankara, Turkey

\begin{abstract}
Aim: Chronic myeloid leukemia (CML) is a hematological malignancy in the group of myeloproliferative neoplasms.Philadelphia chromosome, $t(9 ; 22)(q 34 ; q 11)$, results in the BCR/ABL1 fusion gene. The Philadelphia chromosome could be detected in almost all CML cases.RT-qPCR method is still the most commonly used method for monitoring BCR/ABL1 fusion.RTdigital PCR method is an alternative in quantitative measurement of BCR-ABL1 fusion, but there is not enough information in the literature yet. It was planned to evaluate and compare of RT-qPCR and RT-digital PCR for detection and quantification of BCR-ABL1 transcripts in CML.

Materials and Methods:Totaly, 39CML patients were performed.Total RNA was extracted with RNA extraction kit (QIAamp RNA Blood Mini Kit). Qiagene Rotor-Gene-Q system was used for RT-qPCR method and QX200' ${ }^{\text {TM }}$ Droplet Digital $^{\mathrm{TM}}$ PCR (ddPCR ${ }^{\mathrm{TM}}$ ) system was used for RT-digital PCR testing.

Results:There was significant difference between the groups in the BCRABL1/ABL comparison of the samples ( $p=0.017$ ) (Table 1$)$.

Conclusion:Although the significant difference between RT-digital PCR and RTqPCR in detection and quantification of BCR-ABL1 transcripts in CML, RTdigital PCR is not more sensitive in all samples. Therefore, further research is needed to obtain a clear understanding of the effectiveness of RT-digital PCR.
\end{abstract}

Key Words:Chronic myeloid leukemia, BCR-ABL1, RT-qPCR, RT-digital PCR

Received: 11.07 .2019

Accepted: 11.19 .20
ÖZET

Amaç: Kronik myeloid lösemi (KML), myeloproliferatifneoplaziler içerisinde sınıflanmış bir hematolojik malignitedir. $t(9 ; 22)(q 34 ; q 11)$ translokasyonu ile oluşan Philadelphia kromozomu ile BCR/ABL1 füzyon geni oluşur. Philadelphia kromozomu, neredeyse bütün KML vakalarında tespit edilmektedir. RT-qPCR yöntemi, BCR/ABL1 füzyon geninin kantitatif ölçümünde rutinde en sık kullanılan yöntemdir. RT-dijital PCR yöntemi, alternatif bir yöntem olarak değerlendirilebilir fakat, bu konuda şimdiye kadar literatürde yapılmış yeterli düzeyde çalışma yoktur. Bu çalışmada, RT-qPCR ve RT-dijital PCR yöntemlerinin BCR-ABL1 transkriptlerini tespit etme ve ölçümleme başarılarının kıyaslaması planlandı.

Yöntem:Toplamda $39 \mathrm{KML}$ hastası çalışmaya alındı. RNA izolasyon kiti (QIAamp RNA Blood Mini Kit) ile total RNA izole edildi.RT-qPCR yöntemi için Qiagene Rotor-Gene-Q sistemi,RT-dijital PCR yöntemi içinQX200 ${ }^{\text {TM }}$ Droplet Digital $^{\mathrm{TM}}$ PCR (ddPCR ${ }^{\mathrm{TM}}$ ) sistemi kullanıldı.

Bulgular:Farklı yöntemlerden elde edilen BCR-ABL1/ABL oranları kıyaslandığında iki yöntem arasında anlamlı düzeyde farklılık tespit edildi ( $p=0.017$ ) (Tablo 1).

Sonuç:KML hastalarındaki BCR-ABL1 transkript düzeyinin ölçümünde, RTdijital PCR yöntemi RT-qPCR yöntemine göre anlamlı düzeyde daha hassas bulunmuştur, fakat bu üstünlük tüm örneklerde RT-dijital PCR lehine değildir. Bu sebeple, RT-dijital PCR yönteminin etkinliğinin daha iyi anlaşılabilmesi için daha ileri çalışmalara ihtiyaç vardır.

Anahtar Sözcükler: Kronik myeloid lösemi, BCR-ABL1, RT-qPCR, RT-digital PCR

Geliş Tarihi: 07.11.2019

Kabul Tarihi: 19.11 .2019

Address for Correspondence / Yazışma Adresi: Taha Bahsi, MD University of Health Sciences, Dr. Abdurrahman Yurtaslan Ankara Oncology Training and Research Hospital, Department of Medical Genetics, Ankara, Turkey E-mail: tahabahsi@yahoo.com

CTelif Hakkı 2019 Gazi Üniversitesi Tıp Fakültesi - Makale metnine http://medicaljournal.gazi.edu.tr/ web adresinden ulaşılabilir.

${ }^{\odot}$ Copyright 2019 by Gazi University Medical Faculty - Available on-line at web site http://medicaljournal.gazi.edu.tr/

doi:http://dx.doi.org/10.12996/gmj.2019.111 


\section{INTRODUCTION}

Chronic myeloid leukemia (CML) is a hematological malignancy in the group of myeloproliferative neoplasms (MPN), which is caused by abnormal proliferation of pluripotent stem cells. The prevalence is approximately 1$2 / 100000$ cases in adults, and CML accounts for about $15 \%$ of newly diagnosed leukemia cases (1). CML is more common in males than in females and is diagnosed between $50-60$ years of age. Although the etiology of CML is not fully understood, exposure to ionizing radiation, especially at the early stages of life, may increase the risk (2). CML is the first malignancy associated with a chromosomal abnormality (3). In 1960, Nowel and Hungerford discovered that chromosome 22 was shorter in patients with CML. This short chromosome 22 was called Philedelphia chromosome. Reciprocal translocation between chromosomes 9 and 22 were discovered, 13 years later. Breakpoints are defined on $\mathrm{t}(9 ; 22)(\mathrm{q} 34 ; \mathrm{q} 11)$ (4). This reciprocal translocation results in the $B C R / A B L 1$ fusion gene. This fusion occurs at $5^{\prime}$ end of the BCR gene and $3^{\prime}$ end of the $C-A B L$ proto-oncogene. This newly formed fusion gene produces a protein called p210 weighing $210(\mathrm{kDa})$. The Philadelphia chromosome could be detected in almost all CML cases $(5,6)$. If the breakpoints are different, different proteins are also produced. p190 protein is detected in $5 \%$ of cases; e14a3, e13a3, e1a3, e19a3, e6a2, e8a2 and e18a2 fusion proteins are seen less than $1 \%$. p210 protein has an increased tyrosine kinase activity. Increased tyrosine kinase activity causes the release of growth factors and proliferation of abnormal cell clones (7-10).

CML is usually diagnosed by complet blood count $(C B C)$ in the chronic phase. Leukocytosis, anemia and thrombocytosis are common findings. Bone marrow examination shows hypercellular bone marrow (11). Genetic tests have an importance in the diagnosis and follow-up of CML. The presence of the Philedelphia chromosome in the cytogenetic analysis from the bone marrow sample is diagnostic (12). Molecular cytogenetic method (fluorescence in situ hybridization = FISH) is particularly important when sufficient metaphase cannot be obtained from conventional cytogenetic analysis (13).

Molecular genetic tests are especially important in the follow-up of CML patients, response to treatment, relapse monitoring and also providing prognostic information. A real-time quantitative polymerase chain reaction method (RT-qPCR) is used to measure the amount of BCR-ABL1 fusion as a molecular test (14).This method measures the ratio of BCR/ABL1 fusion transcripts to the number of ABL1 gene transcripts. It is known that the amount of BCR-ABL1 fusion transcript measured by molecular methods is correlated with the number of residual leukemic cells. RT-qPCR method can detect one leukemic cell in 100,000 normal transcripts. According to the molecular result, the molecular response status of the disease is determined during treatment. $\mathrm{BCR}-\mathrm{ABL} 1 /$ control gene ratio $<0.1 \%$ ( $\geq 3$ log reduction) was defined as the major molecular response (MMR), and BCR-ABL1=0 as the full molecular response (CMR) (15).

RT-qPCR method is still the most commonly used method for monitoring molecular response in CML. Residual cell monitoring is actually crucial for early diagnosis of minimal residual disease (MRD). One fusion cell can be detected in 100000 normal copies by RT-qPCR method. Although highly sensitive quantitative results are obtained, more sensitive methods are needed for MRD follow-up, which provide to detect the relapse status of the disease much earlier. RT-digital PCR method have been used in gene expression studies, and detection of hot-spot mutations and single nucleotide changes (CNV), in recent years (16). Although there are studies comparing the success of RTdigital PCR method in quantitative measurement of BCR-ABL1 fusion, there is not enough information in the literature yet $(17,18)$.
In this study, it was planned to evaluate and compare of RT-qPCR and RTdigital PCR for detection and quantification of BCR-ABL1 transcripts in CML.

\section{MATERIALS and METHODS}

Patients and samples

Totaly, 39CML patients were performed at the University of Health Sciences, Dr. Abdurrahman Yurtaslan Ankara Oncology Training and Research Hospital, Medical Genetics Clinic.Ethical committee of Dr. Abdurrahman Yurtaslan Ankara Oncology Training and Research Hospital approved the study (201907/326). Written informed consent was obtained from all patients before testing for the use of their RNA samples for research purposes.Samples were obtained at the same time for RT-qPCR and RT-digital PCR. BCR-ABL1/ABL value was compared with statistical analysis.

\section{$R T$-qPCR testing}

Total RNA from EDTA-anticoagulated peripheral blood was extracted with an RNA extraction kit (QIAamp RNA Blood Mini Kit). RNA was reverse transcribed with an Ipsogen ${ }^{\circ}$ T Kit. CDNA was stored at $-20^{\circ} \mathrm{C}$. BCR-ABL1 CDNA was performed on Qiagene Rotor-Gene- $Q$ with TaqMan probes, according to manufacturer's instructions. Each Ipsogen BCR-ABL1 Mbcr Kit provides four standard dilutions for $A B L$ and five standard dilutions for Mbcr. Use of the Ipsogen BCR-ABL1 Mbcr kits enables detection and quantification of BCR-ABL1 and $A B L$ transcripts. The reaction was initiated according to the optimized protocols defined by the manufacturer.

\section{$R T$-digital PCR testing}

The QX200 ${ }^{\mathrm{TM}}$ Droplet Digital ${ }^{\mathrm{TM}}$ PCR $\left(\mathrm{ddPCR}^{\mathrm{TM}}\right)$ system was used for RT-digital PCR testing. Mastermix was prepared according to manufacturer's instructions. QX200 ${ }^{\mathrm{TM}}$ Droplet Generator hadthree wells per sample. Mastermix was added to the first well and oil was added to the second well for droplet formation. The droplet generator was placed in the wells on the device.The other well was filled with oil. Two minutes later the droplets were ready. Droplets were transferred to PCR plate by pipette.After the PCR, the droplets in the plate were transferred to QX200 ${ }^{\mathrm{TM}}$ Droplet Reader.

\section{Statistical analysis}

The data were evaluated in the SPSS statistical package program (Version 15.0). According to the normal distribution of parameters, concordance was examinedwith visual (histogram and probability graphs) and analytical methods (Kolmogorov-Simirnov / Shapiro-Wilk tests). Because measurements of BCR1/ABL do not show normal distribution, results were compared using Wilcoxon test. Mean value, standard deviation and median-minimummaximum values were given as descriptive statistics, $p<0.05$ was considered statistically significant.

\section{RESULTS}

The amount of BCR/ABL1 fusion transcripts in both RT-qPCR and RT-digital PCR method were compared to 39 patients who were referred to our clinic and followed up with the diagnosis of CML. There was significant difference between the groups in the BCR-ABL1/ABL comparison of the samples ( $p=0.017)$ (Table 1). 
Table 1: Detected BCR/ABL and ABL copy numbers by RT-qPCR and RT-digital PCR.

\begin{tabular}{|c|c|c|c|c|}
\hline \multirow[b]{2}{*}{ Patient (P) } & \multicolumn{2}{|l|}{ RT-qPCR } & \multicolumn{2}{|c|}{ RT-digital PCR } \\
\hline & BCR/ABL & $A B L$ & BCR/ABL & $A B L$ \\
\hline P1 & 0 & 105161 & 0 & 81000 \\
\hline $\mathrm{P} 2$ & 0 & 115620 & 0 & 72000 \\
\hline P3 & 0 & 102885 & 0 & 54000 \\
\hline P4 & 12 & 62200 & 31 & 95670 \\
\hline P5 & 3 & 80877 & 8 & 88670 \\
\hline P6 & 3 & 102885 & 3 & 56000 \\
\hline P7 & 22 & 92223 & 11 & 48000 \\
\hline P8 & 2 & 47489 & 4 & 58160 \\
\hline P9 & 6 & 24995 & 11 & 38000 \\
\hline P10 & 4 & 66906 & 5 & 60000 \\
\hline P11 & 1 & 37330 & 14 & 53000 \\
\hline P12 & 4 & 29132 & 10 & 64000 \\
\hline P13 & 10 & 46123 & 10 & 50000 \\
\hline P14 & 12 & 42879 & 10 & 57000 \\
\hline P15 & 2 & 183059 & 5 & 117000 \\
\hline P16 & 7 & 31796 & 11 & 36000 \\
\hline P17 & 124 & 28920 & 119 & 34000 \\
\hline P18 & 0 & 83271 & 1 & 76000 \\
\hline P19 & 14 & 65458 & 5 & 41000 \\
\hline P20 & 0 & 123465 & 2 & 68000 \\
\hline P21 & 0 & 18569 & 1 & 12000 \\
\hline P22 & 2 & 74464 & 4 & 86000 \\
\hline P23 & 1 & 61437 & 1 & 49000 \\
\hline P24 & 2 & 91547 & 1 & 63000 \\
\hline P25 & 1 & 91500 & 1 & 80000 \\
\hline P26 & 2 & 61437 & 2 & 47000 \\
\hline P27 & 2 & 21565 & 9 & 26000 \\
\hline P28 & 2 & 25585 & 2 & 35000 \\
\hline P29 & 2 & 37318 & 3 & 64000 \\
\hline P30 & 0 & 73411 & 2 & 38000 \\
\hline P31 & 1 & 33776 & 1 & 44000 \\
\hline P32 & 1 & 41525 & 4 & 42000 \\
\hline P33 & 2 & 19106 & 6 & 24000 \\
\hline P34 & 1 & 27085 & 2 & 50000 \\
\hline P35 & 1 & 34018 & 0 & 28000 \\
\hline P36 & 48 & 76616 & 86 & 88000 \\
\hline
\end{tabular}

\section{DISCUSSION}

BCR-ABL1 follow-up is vital in monitoring treatment response, determining resistance development, and reorganizing treatment protocol in CML patients (19). The sensitivity of the follow-up is a necessity in detecting MRD and taking early measures.Genetic diseases diagnostic centers are currently using conventional cytogenetic, FISH and RT-qPCR technologies for routine followup of CML patients. Many studies have been conducted worldwide to find an effective method for MRD detection.In this context, RT-digital PCR method, which has become more widespread in recent years, is considered to be an alternative in the measurement of BCR-ABL1 copy number.

According to the results of the study, both the RT-qPCR method and the RTdigital PCR method were able to detect CML patients with the number of copies on the logarithm of the odds (LOD) value, but there was a difference between the two methods in terms of sensitivity (Table 1). The LOD value shows a higher sensitivity from 1 log to $2 \log$ in a previous study(18).According to another previous study, RT-digital PCR has an comparable performance to RT-qPCR over a 4 log dynamic range for the quantification of BCR-ABL1(17).In this study, there were no differences in logarithmic levels detected in previous studies. On the basis of the differences between the results, the differences in device and kit systems and the characteristics of the study groups can be shown.CML patients included in this study were randomly selected for this study. Future studies can be used to group patients according to the stage of the disease and in which stage the sensitivity increases especially.In this study, RT-digital PCR was found to be more sensitive in low copy numbers. The studies to be conducted in a larger sample of patients with low copy numbers may provide statistically more satisfactory information.

It is thought that simultaneous RT-digital PCR to the sample of the patient, who is considered to be cured, will provide significant information on this subject. In this way, the patient who is considered to be cured with qPCR might be detected with low number of BCR1/ABL copies over the LOD and the treatment may be prolonged.Relapsealso could be detected with this more sensitive method.Early detection of relapse is an important factor that increases treatment success.
Although the significant difference between RT-digital PCR and RT-qPCR in detection and quantification of BCR-ABL1 transcripts in CML, RT-digital PCR is not more sensitive in all samples. Therefore, further research is needed to obtain a clear understanding of the effectiveness of RT-digital PCR.

\section{Conflict of interest}

No conflict of interest was declared by the authors.

\section{REFERENCES}

1.Jabbour E, Kantarjian H. Chronic myeloid leukemia: 2018 update on diagnosis, therapy and monitoring. Am J Hematol 2018; 93: 442-59.

2.Ju FH, Gong XB, Jiang LB, Hong HH, Yang JC, Xu TZ, et al. Chronic myeloid leukaemia following repeated exposure to chest radiography and computed tomography in a patient with pneumothorax: A case report and literature review. Oncol Lett 2016; 11: 2398-402.

3.Thompson PA, Kantarjian HM, Cortes JE. Diagnosis and treatment of chronic myeloid leukemia in 2015. Mayo Clin Proc 2015; 10:1440-54.

4.Lozzio CB, Lozzio BB. Human chronic myelogenous leukemia cell-line with positive Philadelphia chromosome. Blood 1975; 45: 321-34

5.Di Bacco A, Keeshan K, McKenna SL, Cotter TG. Molecular abnormalities in chronic myeloid leukemia: deregulation of cell growth and apoptosis Oncologist 2000; 5: 405-15.

6.Druker BJ, Talpaz M, Resta DJ, Peng B, Buchdunger E, Ford JM, et al. Efficacy and safety of a specific inhibitor of the BCR-ABL tyrosine kinase in chronic myeloid leukemia. N Engl J Med 2001; 344: 1031-7.

7.Al-Achkar W, Moassass F, Youssef N, Wafa A. Correlation of p210 BCR-ABL transcript variants with clinical, parameters and disease outcome in 45 chronic myeloid leukemia patients. J BUON 2016; 21: 444-9.

8.Vinhas R, Cordeiro M, Pedrosa P, Fernandes AR, Baptista PV. Current trends in molecular diagnostics of chronic myeloid leukemia. Leuk Lymphoma 2017; 58: $1791-804$. 
9.Reckel S, Hamelin R, Georgeon S, Armand F, Jolliet Q, Chiappe D, et al. Differential signaling networks of Bcr-Abl p210 and p190 kinases in leukemia cells defined by functional proteomics. Leukemia 2017; 31: 1502.

10.Shet A, Jahagirdar B, Verfaillie C. Chronic myelogenous leukemia: mechanisms underlying disease progression. Leukemia 2002; 16: 1402.

11.Vasconcelos A, Azevedo I, Melo F, Neves W, Azevedo A, Melo R. BCR-ABL1 transcript types showed distinct laboratory characteristics in patients with chronic myeloid leukemia. Genet Mol Res 2017; 16.

12. Kantarjian HM, Talpaz M, Giles F, O'Brien S, Cortes J. New insights into the pathophysiology of chronic myeloid leukemia and imatinib resistance. Ann Intern Med 2006; 145: 913-23.

13. Manaflouyan SK, Rahmani S, Chavoshi SH, Esfahani A, Movassaghpour AA. Reliability Evaluation of Fluorescence In Situ Hybridization (FISH) and GBanding on Bone Marrow and Peripheral Blood Cells in Chronic Myelogenous Leukemia Patients. Cell J 2015; 17: 171-80.
14.Cross NC, White H, Colomer D, Ehrencrona H, Foroni L, Gottardi E, et al. Laboratory recommendations for scoring deep molecular responses following treatment for chronic myeloid leukemia. Leukemia 2015; 29: 999.

15. Press RD. Major molecular response in CML patients treated with tyrosine kinase inhibitors: the paradigm for monitoring targeted cancer therapy. Oncologist 2010; 15: 744-9.

16. Mazaika E, Homsy J. Digital droplet PCR: CNV analysis and other applications. Curr Protoc Hum Genet 2014; 82: 7.24.1-7.24.13.

17.Alikian M, Whale AS, Akiki S, Piechocki K, Torrado C, Myint T, et al. RT-qPCR and RT-digital PCR: a comparison of different platforms for the evaluation of residual disease in chronic myeloid leukemia. Clin Chem 2017; 63: 525-31.

18.Jennings $L$ J, George D, Czech J, Yu M, Joseph L. Detection and quantification of BCR-ABL1 fusion transcripts by droplet digital PCR. J Mol Diagn 2014; 16: 174-9.

19.Ren R. Mechanisms of $B C R-A B L$ in the pathogenesis of chronic myelogenous leukaemia. Nat Rev Cancer 2005; 5: 172. 